\title{
Expression of Bmi-I is a prognostic marker in bladder cancer
} Zi-Ke Qin 1,2, Jian-An Yang1,2, Yun-lin Ye ${ }^{1,2}$, Xing Zhang1,4, Li-Hua Xu',3, FangJian Zhou1,2, Hui Han ${ }^{1,2}$, Zuo-Wei Liu1,2, Li-Bing Song1,3 and MuSheng Zeng*1,3

\begin{abstract}
Address: ${ }^{1}$ State Key Laboratory of Oncology in South China, Sun Yat-sen University Cancer Center, Guangzhou, Guangdong 510060, PR China, 2Department of Urology, Sun Yat-sen University Cancer Center, Guangzhou, Guangdong 510060, PR China, ${ }^{3}$ Department of Experimental Research, Sun Yat-sen University Cancer Center, Guangzhou, Guangdong 510060, PR China and ${ }^{4}$ Department of Biotherapy, Sun Yat-sen University Cancer Center, Guangzhou, Guangdong 510060, PR China

Email: Zi-Ke Qin - qinzike@263.net; Jian-An Yang - doctoryang99@163.com; Yun-lin Ye - yeyunlin2000@yahoo.com.cn; Xing Zhang - xingzhangg@hotmail.com; Li-Hua Xu - xlhua325@126.com; Fang-Jian Zhou - zhoufj@mail.sysu.edu.cn;

Hui Han - hanhui67@sina.com; Zuo-Wei Liu - liuzhuow@mail.sysu.edu.cn; Li-Bing Song - songlib2000@yahoo.com; Mu-

Sheng Zeng* - zengmsh@mail.sysu.edu.cn

* Corresponding author
\end{abstract}

Published: 19 February 2009

BMC Cancer 2009, 9:6I doi:10.1 |86/|47|-2407-9-61
Received: I September 2008

Accepted: 19 February 2009

This article is available from: http://www.biomedcentral.com/I47/-2407/9/6I

(C) 2009 Qin et al; licensee BioMed Central Ltd.

This is an Open Access article distributed under the terms of the Creative Commons Attribution License (http://creativecommons.org/licenses/by/2.0), which permits unrestricted use, distribution, and reproduction in any medium, provided the original work is properly cited.

\begin{abstract}
Background: The molecular mechanisms of the development and progression of bladder cancer are poorly understood. The objective of this study was to analyze the expression of Bmi-I protein and its clinical significance in human bladder cancer.

Methods: We examined the expression of Bmi-I mRNA and Bmi-I protein by RT-PCR and Western blot, respectively in 14 paired bladder cancers and the adjacent normal tissues. The expression of Bmi-I protein in 137 specimens of bladder cancer and 30 specimens of adjacent normal bladder tissue was determined by immunohistochemistry. Statistical analyses were applied to test the relationship between expression of Bmi- I, and clinicopathologic features and prognosis.

Results: Expression of Bmi-I mRNA and protein was higher in bladder cancers than in the adjacent normal tissues in 14 paired samples $(P<0.01)$. By immunohistochemical examination, five of 30 adjacent normal bladder specimens $(16.7 \%)$ versus 75 of I 37 bladder cancers $(54.3 \%)$ showed Bmi-I protein expression $(P<0.05)$. Bmi-I protein expression was intense in $20.6 \%, 54.3 \%$, and $78.8 \%$ of tumors of histopathological stages GI, G2, and G3, respectively $(P<0.05)$. Expression of Bmi-I protein was greater in invasive bladder cancers than in superficial bladder cancers $(81.5 \%$ versus $32.5 \%, P<0.05)$. In invasive bladder cancers, the expression of Bmi-I protein in progression-free cancers was similar to that of cancers that have progressed $(80.0 \%$ versus $82.4 \%, P>0.5)$. In superficial bladder cancers, the expression of Bmi-I protein in recurrent cases was higher than in recurrence-free cases $(62.5 \%$ versus $13.7 \%, P<0.05)$. Bmi-I expression was positively correlated with tumor classification and TNM stage $(P<0.05)$, but not with tumor number $(P>0.05)$. Five-year survival in the group with higher Bmi-I expression was $50.8 \%$, while it was $78.5 \%$ in the group with lower Bmi-I expression $(P<0.05)$. Patients with higher Bmi-I expression had shorter survival time, whereas patients with lower Bmi-I expression had longer survival time $(P<0.05)$.
\end{abstract}

Conclusion: Expression of Bmi-I was greater in bladder cancers than in the adjacent normal tissues. The examination of Bmi-I protein expression is potentially valuable in prognostic evaluation of bladder cancer. 


\section{Background}

Bladder cancer is one of the most lethal urological malignant tumors worldwide[1]. Although the treatment of bladder cancer has improved greatly in recent years, the incidence of this disease is gradually increasing [2]. More than half of the patients with bladder cancer have advanced stage disease with very poor prognosis[3]. Although some environmental factors and genetic factors have been associated with bladder cancer [4-6], the molecular mechanisms involved in the initiation and progression of bladder cancers remain unclear.

The BMI1 gene was first isolated as an oncogene that cooperated with c-Myc in generating lymphomas in a murine model[7,8]. It is a transcriptional repressor belonging to the Polycomb-group (PcG) family of proteins involved in axial patterning, hematopoiesis, regulation of proliferation, and senescence [9-11]. The BMI1 gene also was reported to immortalize bone marrow stromal cells and cementoblast progenitor cells, albeit in combination with other oncogenes $[12,13]$. In addition, the $B M I 1$ gene plays an important role in cell proliferation and tumor progression [14-18]. The BMI1 gene is widely expressed in diverse human tumors, including lymphomas, non-small cell lung cancer, B-cell non-Hodgkin's lymphoma, breast cancer, colorectal cancer, and neuroblastoma [14-21], and has been shown to be a useful prognostic marker in myelodysplastic syndrome and many cancers, including nasopharyngeal carcinoma and gastric cancer [14-21].

However, there is no published report on the expression of Bmi-1 in bladder cancer. In this study we aimed to explore the expression of Bmi-1 protein and its clinical significance in human bladder cancers.

\section{Methods}

\section{Patients and tissue specimens}

For RT-PCR and Western blot analysis, we collected 14 paired transitional cell bladder cancers and adjacent normal tissues from the patients who underwent surgery between March 2008 and April 2008. In addition, 137 paraffin-embedded samples of transitional cell bladder cancer and 30 specimens of adjacent normal bladder tissue were collected between 2000 and 2003 for immunohistochemical assay. All tumors were histologically and clinically diagnosed by the cancer center of Sun Yat-sen University. For the use of these clinical materials, prior patient consent, and approval from the institute research ethics committee (Approval number: YP2008063) were obtained.

The disease stage of each patient was classified or reclassified according to the 2002 AJCC staging system[22]. The 137 patients included 115 males and 22 females from 14 to 72 years (mean, 56 years). Of these patients, 41 patients underwent radical cystectomy, 20 patients underwent partial cystectomy, and 76 patients underwent TURBT (transurethral resection of bladder tumor). After partial cystectomy and TURBT, mitomycin C was used in intravesical therapy as weekly intravesical injection beginning within 24 hours after surgery. Thirty specimens of adjacent normal bladder tissue distant from the tumor were included for these patients, as well. The median follow-up time for overall survival was 56 months for patients still alive at the time of analysis, ranging from 11 to 86 months.

\section{Reverse transcription - PCR analysis}

Total mRNA was purified using TRIzol Reagent (Invitrogen, Carlsbad, CA, USA), and $1 \mu \mathrm{g}$ of each sample was reverse transcribed using TIAN Script Kit (TIANGEN, Beijing, China). The BMI1 sense primer was 5'AGCAGAAATGCATCGAACAA-3', and the antisense primer was 5 'CCTAACCAGATGAAGTTGCTGA-3'. For the $\beta$-actin gene, the sense primer was 5'CCCCTGGCCAAGGTCATCCATGACAACTTT-3', and the antisense primer was 5'GGCCATGAGGTCCACCACCCTGTTGCTGTA-3'. PCR reactions were performed following the cycling parameters on a PTC-200 PCR system (Bio-Rad, Hercules, Calif): $10 \mathrm{~min}$ at $94^{\circ}$ followed by 28 cycles of $1 \mathrm{~min}$ at $94^{\circ}, 1$ $\min$ at $55^{\circ}, 1 \mathrm{~min}$ at $72^{\circ}$, and a final cycle at $72^{\circ} \mathrm{C}$ for 10 min. PCR products were scanned, and quantification was performed by the Quantity One program (Bio-Rad, Hercules, CA).

\section{Western blot analysis}

Total proteins were extracted with $1 \times$ SDS sample buffer [62.5 mmol/L Tris-HCl (pH 6.8), 2\% SDS, 10\% glycerol, and 5\% 2-mercaptoethanol], and $30 \mu \mathrm{g}$ of each protein was electrophoretically separated in $12 \%$ SDS polyacrylamide gels, and transferred to polyvinylidene difluoride membranes (Millipore). Rabbit polyclonal anti-Bmi-1 (1:800, Upstate Biotechnology, Lake Placid, NY) and antiRabbit (1:2000, Santa Cruz Biotechnology, Santa Cruz, $\mathrm{CA}$ ) antibodies were used to detect Bmi-1 protein. Mouse anti- $\alpha$-tubulin (1:2000, Sigma) and anti-mouse (1:2000, Santa Cruz Biotechnology, Santa Cruz, CA) antibodies were used to detect $\alpha$-tubulin. The Western blot bands were scanned and were analyzed by the Quantity One program (Bio-Rad, Hercules, CA).

\section{Immunohistochemistry assay}

Immunohistochemistry was performed to examine Bmi-1 expression in 137 human bladder cancers and 30 specimens of adjacent normal bladder tissue. The procedures were performed with classical protocols. In brief, paraffinembedded specimens were cut into $4-\mu \mathrm{m}$ sections and baked at $65^{\circ}$ for $30 \mathrm{~min}$. The sections were deparaffinized with xylene and rehydrated. Sections were submerged into 
EDTA antigenic retrieval buffer and microwaved for antigenic retrieval. The sections were then treated with 3\% hydrogen peroxide in methanol to quench the endogenous peroxidase activity, followed by incubation with $1 \%$ bovine serum albumin to block the nonspecific binding.

The Bmi- 1 protein was detected using a mouse monoclonal antibody against Bmi-1 (Upstate Biotechnology, Lake Placid, NY). The specimens were incubated with anti-Bmi- 1 antibody $(1: 100)$ overnight at $4^{\circ}$. In the negative control, primary antibody was replaced by the nonimmune mouse IgG of the same isotype. After washing, the tissue sections were treated with biotinylated antimouse secondary antibody followed by further incubation with a streptavidin-horseradish peroxidase complex. The tissue sections were immersed in 3-amino-9-ethyl carbazole, and counterstained with 10\% Mayer's hematoxylin, dehydrated, and mounted in Crystal Mount.

The degree of immunostaining of formalin-fixed, paraffin-embedded sections was reviewed and scored by two independent observers. The proportion of cells expressing Bmi-1 varied from $0 \%$ to $100 \%$, and the intensity of nuclear staining varied from weak to strong. Cells were scored for intensity of staining on a scale of 0 (no staining), 1 (weak staining, light yellow), 2 (moderate staining, yellowish brown), and 3 (strong staining, brown). Using this method of assessment, we evaluated the expression of Bmi-1 in bladder cancer tissue and in normal bladder tissue. An optimal cutoff value was identified. An intensity score of $=2$ with at least $50 \%$ of malignant cells positive for Bmi-1 staining was used to classify tumors with high expression, and $<50 \%$ of malignant cells with nuclear staining of intensity score of $<2$ characterized tumors with low expression of Bmi-1.

\section{Statistical analysis}

All statistical analyses were carried out with the SPSS 13.0 statistical software package. In the RT-PCR and Western blot analysis, t-test was used to analyze the significance of mRNA and protein expression between bladder cancers and the adjacent normal tissues. We analyzed the relationship between expression of Bmi-1 protein, clinicopathologic features, and the clinical prognosis. The $\chi^{2}$ test for proportion was used to analyze the relationship between Bmi-1 expression and clinicopathologic characteristics. Survival curves were plotted by the Kaplan-Meier method, and compared by the log-rank test. We determined that the assumption of proportional hazards was met in all Cox regression models. The significance of various variables for survival was analyzed by the Cox proportional hazards model in the multivariate analysis. $P<0.05$ was considered statistically significant.

\section{Results \\ Expression of Bmi-I mRNA and protein in paired bladder tissues}

To ensure the reliability of this study, we first examined the expression of Bmi-1 mRNA and Bmi-1 protein by RTPCR and Western blot, respectively in 14 bladder cancers. The control samples were paired adjacent normal tissues taken from the same patients. The relative level of Bmi-1 expression was compared in bladder cancers and the adjacent normal tissue (Figs. 1 and 2). The expression levels were determined as a ratio between Bmi-1 and the reference protein ( $\alpha$-tubulin) or gene ( $\beta$-actin) to correct for variation in the quantity of protein and mRNA. In the RTPCR analysis, the ratios (bladder cancer/normal tissue) were $4.97,1.63,1.37,1.71,1.09,1.30,2.19,1.75,2.05$, $6.73,1.28,1.84,12.67$, and 1.42 , respectively. In the Western blot analysis, the ratios (bladder cancer/normal tissue) were $10.71,8.99,6.05,2.97,2.55,6.09,35.47$, $1.95,2.12,3.14,7.42,2.32,5.46$, and 32.47 , respectively.

Expression of both mRNA and protein was found to be higher in tumor tissues than in the paired adjacent normal tissues $(P<0.01)$. Bmi-1 protein expression is up-regu-

$\mathbf{A}$

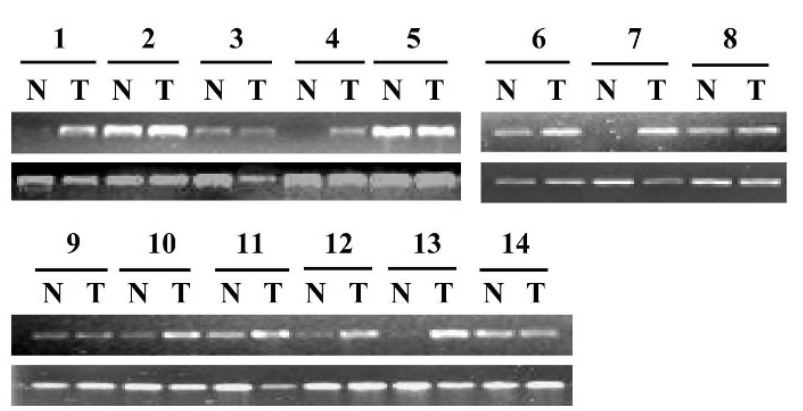

B

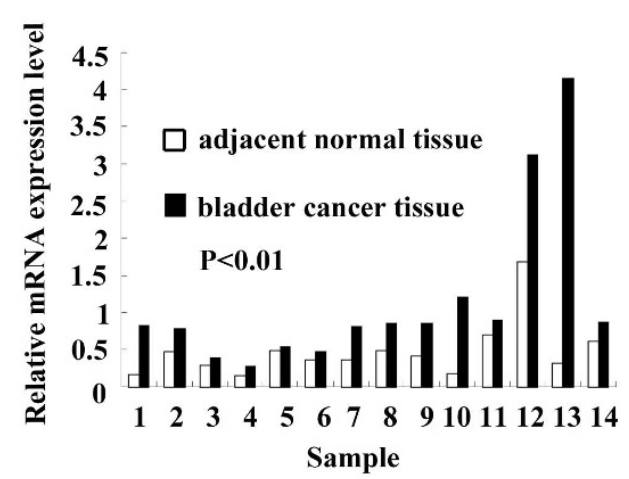

Figure I

Expression of Bmi-I mRNA in paired bladder cancers and the adjacent normal tissues by RT-PCR analysis. A: RT-PCR analysis in 14 paired bladder cancers and the adjacent normal tissues (upper panel); $\beta$-actin as the internal control (showed in lower panel). B: The relative expression level of Bmi-I in comparison to the expression level of $\beta$-actin. 
A

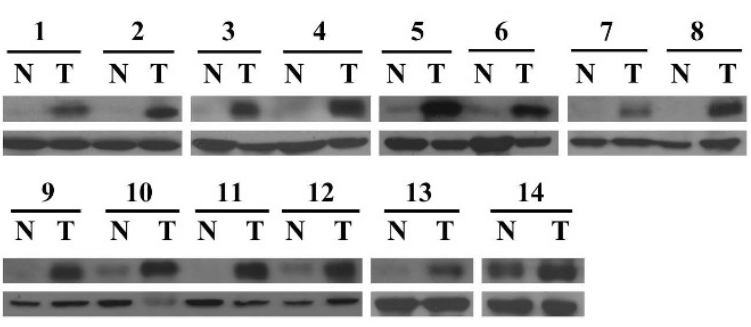

B

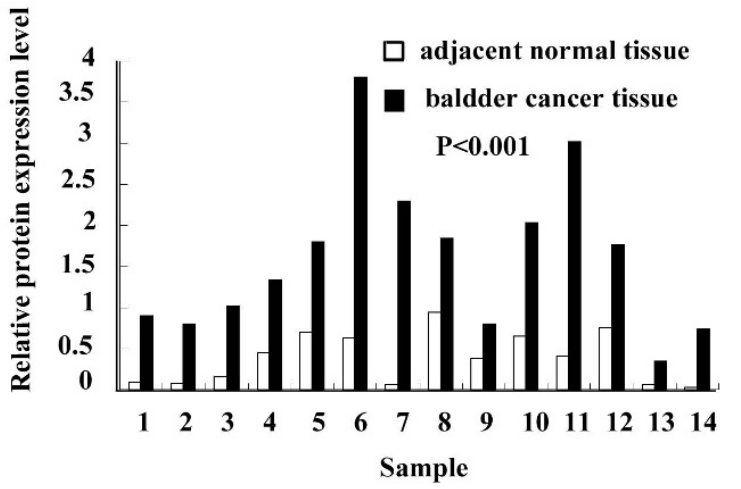

Figure 2

Expression of Bmi-I protein in paired bladder cancers and the adjacent normal tissues by Western Blot analysis. A: Western Blot analysis in 14 paired bladder cancers and the adjacent normal tissues (upper panel); $\alpha$ tubulin as the loading control (showed in lower panel). B: The relative expression level of Bmi- I in comparison to the expression level of $\alpha$-tubulin.

lated to a greater extent than is Bmi- 1 mRNA expression in cancer tissues relative to non-cancerous tissues.

\section{Expression of Bmi-I protein in paraffin-embedded bladder cancer samples}

Expression and subcellular localization of Bmi-1 protein were determined by immunohistochemistry in 137 paraffin-embedded bladder cancer tissues, and 30 specimens of adjacent normal bladder tissues. In non-cancerous tissues, Bmi-1 protein staining was present in few cells, and the protein staining was very weak (Fig. 3A, B). In tumor tissues, specific Bmi-1 signals were localized mainly in the nuclei of carcinoma cells in the form of yellow-brown granules (Fig. 3C, D). Bmi-1 protein expression was high in $54.3 \%$ of bladder cancers, while Bmi- 1 expression was observed in only $16.7 \%$ of adjacent normal tissues $(P<$ $0.05)$.

\section{Relationship between Bmi-I protein expression and clinicopathological features}

The relationship between the expression of Bmi-1 protein and clinical characteristics is shown in Table 1. Intense expression of Bmi-1 in bladder cancer was positively cor-
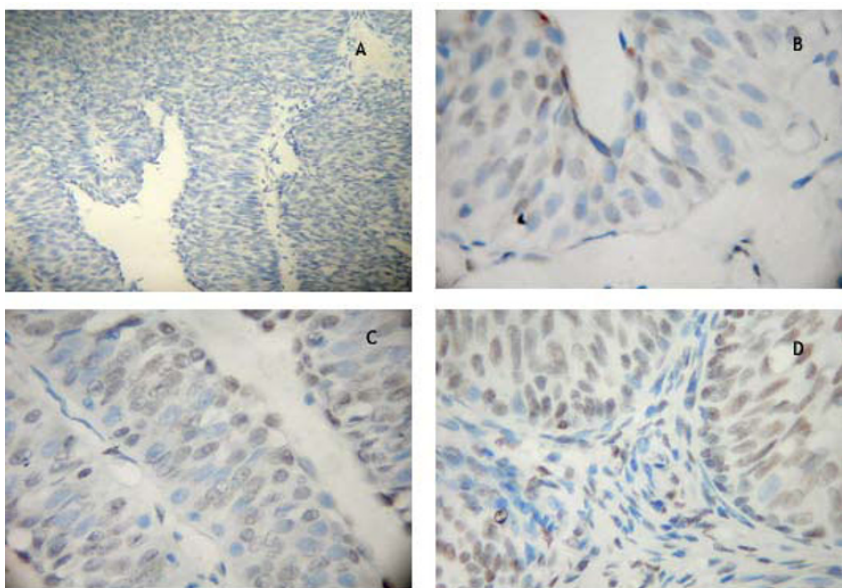

Figure 3

Expression analysis of Bmi-I protein by immunohistochemistry. Bmi- I staining was mainly localized within the nuclei, and it expressed was observed in cancer cell. A: Negative $\mathrm{Bmi}-\mathrm{I}$ staining in non-cancerous tissue (I00x). B: Weak Bmi-I staining in non-cancerous cells(400x). C: strong Bmi-I staining in tumor nests(400x). D: Strong nuclear stainingin most of the tumor cells (400x).

related with the histopathological classification, clinical stage, and recurrence $(P<0.05)$; but was not correlated with gender, age, or tumor number $(P>0.05)$. Intense expression of Bmi-1 protein was noted in 20.6\%, 54.3\%, and $78.8 \%$ of bladder tumors of histopathological grade G1, G2, and G3, respectively $\left(P<0.05, \chi^{2}\right.$ test $)$. Intense

Table I: Correlation between Bmi-I expression and clinicalpathologic features of the patient with bladder cancer

\begin{tabular}{|c|c|c|c|c|}
\hline \multirow[b]{2}{*}{ Characteristics } & \multirow[b]{2}{*}{$\mathrm{n}$} & \multicolumn{2}{|c|}{ Bmi-I expression } & \multirow[t]{2}{*}{$P$} \\
\hline & & Low & High & \\
\hline \multicolumn{5}{|l|}{ Gender } \\
\hline Male & 115 & 58 (50.4\%) & 57 (49.6\%) & 0.226 \\
\hline Female & 22 & $8(36.4 \%)$ & $14(63.6 \%)$ & \\
\hline \multicolumn{5}{|l|}{ Age } \\
\hline$\leq 50$ & 49 & $26(53.1 \%)$ & $23(46.9 \%)$ & 0.393 \\
\hline$>50$ & 88 & 40 (45.5\%) & 48 (54.5\%) & \\
\hline \multicolumn{5}{|c|}{ Tumor number } \\
\hline$\leq 3$ & 91 & 47 (5I.6\%) & 44 (48.4\%) & 0.255 \\
\hline$>3$ & 46 & $19(41.3 \%)$ & 27 (58.7\%) & \\
\hline \multicolumn{5}{|c|}{ Histological grade } \\
\hline$G_{1}$ & 34 & 27 (79.4\%) & $7(20.6 \%)$ & 0.001 \\
\hline $\mathrm{G}_{2}$ & 70 & $32(45.7 \%)$ & $38(54.3 \%)$ & \\
\hline $\mathrm{G}_{3}$ & 33 & $7(21.2 \%)$ & 26 (78.8\%) & \\
\hline \multicolumn{5}{|l|}{ Clinical stage } \\
\hline$T_{a}, T_{1}$ & 83 & $56(67.5 \%)$ & 27 (32.5\%) & 0.001 \\
\hline $\mathrm{T}_{2}, \mathrm{~T}_{3}, \mathrm{~T}_{4}$ & 54 & $10(18.5 \%)$ & 44 (8I.5\%) & \\
\hline \multicolumn{5}{|c|}{ Superficial cancer } \\
\hline No recurrence & 51 & $44(86.3 \%)$ & 7 (13.7\%) & 0.001 \\
\hline Recurrence & 32 & $12(37.5 \%)$ & $20(62.5 \%)$ & \\
\hline
\end{tabular}


expression of Bmi-1 protein was noted in $81.5 \%$ of invasive bladder cancer and $32.5 \%$ of superficial bladder cancer $(P<0.05)$. In invasive bladder cancers, expression of Bmi-1 protein in progression-free cancers was similar to that of cancers with progression $(80.0 \%$ versus $82.4 \%, P>$ $0.5)$. In superficial bladder cancers, Bmi-1 protein was highly expressed in $62.5 \%$ in recurrent cases versus $13.7 \%$ of recurrence-free cases $(P<0.05)$.

\section{Survival analysis}

Kaplan-Meier analysis and the log-rank test were used to calculate the effect of the Bmi-1 expression on survival. The five-year survival in the group of higher Bmi-1 expression was $50.8 \%$, but it was $79.0 \%$ in the group of lower Bmi-1 expression. The log-rank test showed that survival was significantly different between these two groups $(P=$ $0.0197)$. The expression level of Bmi-1 protein in bladder cancer was significantly correlated with patient survival $(P$ $<0.001$ ), and the correlation coefficient was -0.27 , indicating that a higher level of Bmi-1 expression was correlated with shorter survival time. The low Bmi-1 expression group had longer survival, whereas the high Bmi-1 expression group had shorter survival (Fig. 4). In addition, we did multivariate survival analysis, which included Bmi-1 expression level, histological classification, and clinical stage to test the independent effects of Bmi-1 on survival. We found that Bmi-1 expression, histological classification, and clinical stage were independent predictors of survival (Table 2). Thus, our findings indicate that the Bmi-1 protein expression level has a significant correlation with clinicopathological features, and is a potential prognostic marker for bladder cancer.

\section{Discussion}

At present, the molecular mechanisms of the initiation and progression of bladder cancers are unclear, although many genetic factors have been found to be associated with bladder cancer [4-6]. In this study, we report that Bmi-1 is overexpressed in human bladder cancers. The overexpression of Bmi-1 protein was correlated with tumor classification, recurrence, TNM stage, and prognosis. Patients with higher Bmi-1 expression had shorter survival time, and patients with lower Bmi-1 expression had a longer survival time.

This study demonstrated that there was a significant difference in Bmi-1 expression at both protein and mRNA levels between bladder cancer cells and the adjacent normal bladder tissue. Furthermore, Bmi-1 protein is up-regulated to a much greater extent than is Bmi- 1 mRNA in cancer tissue compared with non-cancerous tissues. This observation suggests that dysregulation at the posttranscriptional level might be the major source of Bmi-1 expression in bladder cancers. Immunohistochemistry demonstrated that bladder cancers showed moderate to strong nuclear staining, while adjacent normal tissues showed only weak Bmi-1 expression, or no Bmi-1 expression at all. These results were similar to those of previous studies of other human cancers [14-18]. Furthermore, intense expression of Bmi-1 in bladder cancer correlated with its clinicopathologic features including tumor classification, recurrence, and TNM stage. Previous reports indicated that the BMI1 gene may be a novel molecular marker to predict the progression and prognosis of breast cancer and myelodysplastic syndrome (MDS) $[19,20,23,24]$. Consistent with previous reports of other cancers, over-expression of Bmi-1 protein indicated poor prognosis for patients with bladder cancer. The fiveyear survival was significantly different between the two groups, and the results showed that the greater the expression of Bmi-1 protein, the lower the survival rate.

The initiation and progression of bladder cancer involve a series of genetic events including activation of oncogenes, and the inactivation of tumor suppressors $[6,25,26]$. The regulatory mechanism of the Polycomb group proteins relies upon epigenetic modifications of specific histone tails that are inherited through cell division[10,27].

Table 2: Overall survival analysis of different prognostic variable in patients with bladder cancer by Cox Regression Analysis

\begin{tabular}{|c|c|c|c|c|c|}
\hline & \multirow[b]{2}{*}{$\mathrm{n}$} & \multicolumn{2}{|r|}{ Univariate analysis } & \multicolumn{2}{|r|}{ Multivariate analysis } \\
\hline & & $P$ & Hazard ratios ( $95 \%$ confidence interval) & $P$ & Hazard ratios ( $95 \%$ confidence interval) \\
\hline \multicolumn{6}{|c|}{ Clinical stage } \\
\hline $\mathrm{T}_{\mathrm{a}} \mathrm{T}_{\mathrm{l}}$ & 83 & & & & \\
\hline $\begin{array}{c}\mathrm{T}_{2} \mathrm{~T}_{3} \mathrm{~T}_{4} \\
\text { Histologica }\end{array}$ & 54 & & \multicolumn{3}{|c|}{ Histological grade } \\
\hline $\mathrm{G}_{1}$ & 34 & 0.003 & $2.412(1.302-3.673)$ & 0.005 & $2.749(1.437-3.758)$ \\
\hline $\mathrm{G}_{2}$ & 70 & & & & \\
\hline $\mathrm{G}_{3}$ & 33 & & & & \\
\hline \multicolumn{6}{|c|}{ Bmi-I expression } \\
\hline High & 75 & 0.022 & $1.653(1.121-3.485)$ & 0.032 & $1.863(1.132-3.753)$ \\
\hline Low & 62 & & & & \\
\hline
\end{tabular}




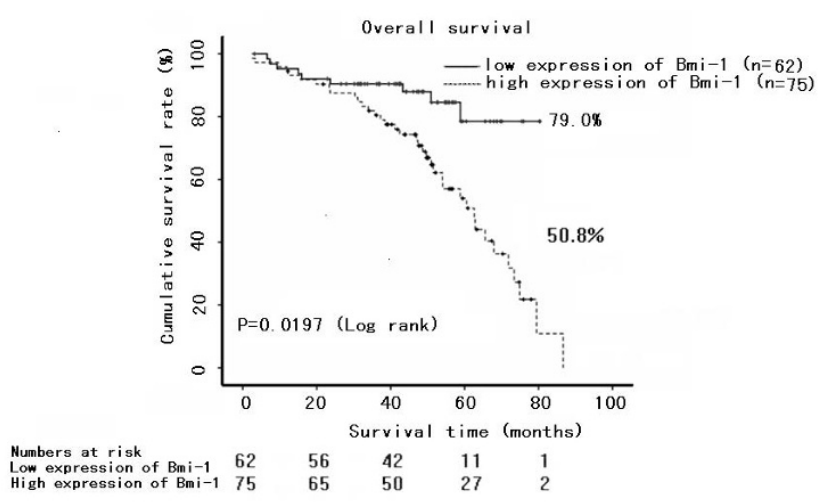

Figure 4

Survival curves of patients with bladder cancer, subdivided according to $\mathrm{Bmi}-\mathrm{I}$ protein expression. The 5year survival rate was $79.0 \%$ in the Bmi-I (low) group $(n=62)$ and it was $50.8 \%$ in the Bmi-I (high) group $(n=75)$. The longest follow-up time is 86 months.

Because Bmi-1 is a member of the PcG family, Bmi- 1 overexpression could repress the p16Ink4a (CDKN2A) and p19Arf targets $[17,20]$. In the absence of p16Ink4a, the cyclin D/Cdk4/ 6 complex can phosphorylate pRB, allowing the E2F-dependent transcription that leads to cell cycle progression and DNA synthesis. Bmi-1-deficient mouse embryonic fibroblasts (MEF) overexpress INK4a/ ARF locus-encoded genes CDKN2A and p19ARF (mouse homologue of human p14ARF) and undergo premature senescence in culture[28].

Conversely, overexpression of Bmi-1 reduces expression of p16INK4a and p19ARF, and immortalizes MEFs[28]. Kang[29] found that Bmi-1 may act through a p16INK4Aindependent pathways to regulate cellular proliferation during progression of oral cancer. In addition, MDM2mediated p53 degradation causes low p53 levels in the absence of p19Arf, thus preventing cell cycle arrest and apoptosis[30]. The BMI1 gene also can induce telomerase activity to prevent apoptosis. Other investigators have found that the frequent inactivation of the p14ARF and CDKN2A genes may be an important mechanism for the dysfunction of p53 and $\mathrm{Rb}$ growth regulatory pathways during bladder cancer development [31-34]. However, whether overexpression of BMI1 results in reduction of p14ARF and CDKN2A gene expression requires further investigation.

In our experience, the clinicopathologic features of bladder cancer are closely related to its prognosis. In our study, we found that in addition to T classification and TNM stage, Bmi-1 expression is an independent prognostic factor for bladder cancers. In the literature, the BMI1 gene is reported to be related to the clinicopathologic features and prognosis in other human cancers, including breast cancer, colon cancer, and lung cancer [19-21]. Thus, we believe that the BMI1 gene probably plays an important role in cell proliferation and tumor progression in bladder cancers. More studies are required to explore the relationships between the BMI1 gene and other genes such as p14, p16, and TP53, and its relationship to other molecules that may be associated with bladder cancer.

\section{Conclusion}

This study demonstrated overexpression of Bmi-1 in bladder cancers. The overexpression of Bmi-1 protein was correlated with tumor classification, recurrence, clinical stage, and prognosis. Greater expression of Bmi-1 protein predicts a lower degree of differentiation, higher recurrence risk, and poorer prognosis. These results indicate that the BMI1 gene may play an important role in the progression of bladder cancer; however, this study has several limitations. In this study, the old WHO grading system (grades 1, 2, and 3) was used, and lymphovascular invasion was not recorded. In addition, we can say only that Bmi-1 expression is an independent prognostic marker for bladder cancer. It may offer new information that stage and grade cannot provide, but more evidence is required to support this conclusion. Prospective studies, additional cases, and different antibodies would be required to test the relationship between Bmi-1 expression and the clinical biological behavior of bladder cancer.

\section{Competing interests}

The authors declare that they have no competing interests.

\section{Authors' contributions}

ZKQ, JAY and YLY were responsible for data collection and analysis, experiment job, interpretation of the results, and writing the manuscript. FJZ, HH, XZ, ZWL and SLB were responsible for conducting the data analysis, reviewing and scoring the degree of immunostaining of sections in cooperation with JAY. MSZ and ZKQ were responsible for experimental design, analysis and interpretation. All authors have read and approved the final manuscript.

\section{Acknowledgements}

This work was supported by a grant of Science and Technology Project of Guangdong Province (No.2004), grants from Ministry of Science and Technology of China (No. 2007AA02Z477 and 2006AA02Z4B4) and a key grant from National Natural Science Foundation of China (No. 30630068).

\section{References}

I. Greenlee RT, Hi-Harmon MB, Murray T, Thun M: Cancer Statistics, 200 I. CA Cancer J Clin 200I, 5 I:I5-36.

2. Laufer M, Ramalingam S, Schoenberg MP, Haisfield-Wolf ME, Zuhowski EG, Trueheart IN, Eisenberger MA, Nativ O, Egorin MJ: Intravesical Gemcitabine therapy for superficial transitional cell carcinoma of the bladder phase I and pharmacokinetic study. J Clin Oncol 2003, 2 1:697-703.

3. Stein JP, Grossfeld GD, Ginsberg DA, Esrig D, Freeman JA, Figueroa AJ, Skinner DG, Cote RJ: Prognostic markers in bladder cancer: 
a contemporary review of the literature. I Urol 1998, 160:645-659.

4. Eissa S, Kassim S, El-Almady O: Detection of bladder tumours role of cytology, morphology-based assays, biochemical and molecular markers. Cuur Opin Obstet Gynecol 2003, 15:395-403.

5. Shinka T, Ogura H, Morita T, Nishikawa T, Fujinaga T, Ohkawa T: Relationship between glutathione S-transferase MI deficiency and urothelial cancer in dye workers exposed to aromatic amine. J Urol 1998, 159:380-383.

6. Shariat SF, Karam JA, Lerner SP: Molecular markers in bladder cancer. Curr Opin Urol 2008, 18: I-8.

7. Haupt Y, Alexander WS, Barri G, Klinken SP, Adans JM: Novel zinc finger gene implicated as myc collaborator by retrovirally accelerated lymphomagenesis in Emu-myc transgenic mice. Cell 1991, 65:753-763.

8. van Lohuizen M, Verbeek S, Scheijen B, Wientjens E, van der Gulden $\mathrm{H}$, Bems $\mathrm{A}$ : Identification of cooperating oncogenes in $E$ mumyc transgenic mice by provirus tagging. Cell 1991, 65:737-752.

9. Lugt NM van der, Domen J, Linder sK, van Roon M, Robanus-Maandag E, te Riele H, Valk M van der, Deschamps J, Sofroniew M, van Lohuizen M: Posterior transformation, neurological abnormalities, and severe hematopoietic defects in mice with a targeted deletion of the bmi-I proto-oncogene. Genes Dev 1994, 8:757-769.

10. Pirrotta V: Polycombing the genome: PcG, trxG, and chromatin silencing. Cell 1998, 93:333-336.

II. Lessard J, Sauvageau G: Bmi-I determines the proliferative capacity of normal and leukaemic stem cells. Nature 2003, 423:255-60.

12. Saito M, Handa K, Kiyono T, Hattori S, Yokoi T, Tsubakimoto T, Harada H, Noguchi T, Toyoda M, Sato S, Teranaka T: Immortalization of cementoblast progenitor cells with Bmi-I and TERT. Jone Miner Res 2005, 20:50-57.

13. Mori T, Kiyono T, Imabayashi H, Takeda $\mathrm{Y}$, Tsuchiya K, Miyoshi S, Makino $H$, Matsumoto K, Saito $H$, Ogawa S, Sakamoto M, Hata J, Umezawa A: Combination of hTERT and bmi-I, E6, or E7 induces prolongation of the life span of bone marrow stromal cells from an elderly donor without affecting their neurogenic potential. Mol Cell Biol 2005, 25:5I83-5I95.

14. Beà $S$, Tort $F$, Pinyol $M$, Puig $X$, Hernández L, Hernández $S$, Fernandez PL, van Lohuizen M, Colomer D, Campo E: BMI-I gene amplification and overexpression in hematological malignancies occur mainly in mantle cell lymphomas. Cancer Res 200I, 6I:2409-24I2.

15. Vonlanthen S, Heighway J, Altermatt HJ, Gugger M, Kappeler A, Borner MM, van Lohuizen M, Betticher DC: The bmi-I oncoprotein is differentially expressed in nonsmall cell lung cancer and correlates with INK4A-ARF locus expression. Br J Cancer 200I, 84: I372-I376.

16. van Kemenade FJ, Raaphorst FM, Blokzijl T, Fieret E, Hamer KM, Satijn DP, Otte AP, Meijer CJ: Coexpression of BMI-I and EZH2 polycomb-group proteins is associated with cycling cells and degree of malignancy in B-cell non-Hodgkin lymphoma. Blood 2001, 97:3896-3910.

17. Kim JH, Yoon SY, Jeong SH, Kim SY, Moon SK, Joo JH, Lee Y, Choe IS, Kim JW: Overexpression of Bmi-I oncoprotein correlates with axillary lymph node metastases in invasive ductal breast cancer. Breast 2004, I3:383-388.

18. Cui H, Hu B, Li T, Ma J, Alam G, Gunning WT, Ding HF: Bmi-I is essential for the tumorigenicity of neuroblastoma cells. $\mathrm{Am} J$ Pathol 2007, I70:1370-1378.

19. Mihara K, Chowdhury M, Nakaju N, Hidani S, Ihara A, Hyodo H, Yasunaga S, Takihara $Y$, Kimura A: Bmi-I is useful as a novel molecular marker for predicting progression of myelodysplastic syndrome and prognosis of the patients. Blood 2006, 107:305-308.

20. Song LB, Zeng MS, Liao WT, Zhang L, Mo HY, Liu WL, Shao JY, Wu QL, Li MZ, Xia YF, Fu LW, Huang WL, Dimri GP, Band V, Zeng YX: $\mathrm{Bmi}-\mathrm{I}$ is a novel molecular marker of nasopharyngeal carcinoma progression and immortalizes primary human nasopharyngeal epithelial cells. Cancer Res 2006, 66:6225-6232.

21. Breuer RH, Snijders PJ, Sutedja GT, Sewalt RG, Otte AP, Postmus PE, Meijer CJ, Raaphorst FM, Smit EF: Expression of the p I6(INK4a) gene product, methylation of the pl6(INK4a) promoter region and expression of the polycomb-group gene BMI-I in squamous cell lung carcinoma and premalignant endobronchial lesions. Lung Cancer 2005, 48:299-306.

22. Greene FL, Balch CM, Fleming ID, Fritz A, Haller DG, Morrom M, David L: AJCC Cancer Staging Manual. 6th edition. New York: AJCC Springer-Verlag; 2002:335-340.

23. Silva J, García V, García JM, Peña C, Domínguez G, Díaz R, Lorenzo Y, Hurtado A, Sánchez A, Bonilla F: Circulating Bmi-I mRNA as a possible prognostic factor for advanced breast cancer patients. Breast Cancer Res 2007, 9:55.

24. Chowdhury M, Mihara K, Yasunaga S, Ohtaki M, Takihara Y, Kimura A: Expression of Polycomb-group (PcG) protein BMI-I predicts prognosis in patients with acute myeloid leukemia. Leukemia 2007, 21: I I 16-I I 22

25. Sandberg AA, Berger CS: Review of chromosome studies in urological tumors. Cytogenetics andmolecular genetics of bladder cancer. J Urol 1994, 15 I:545-560.

26. Knowles MA: Molecular genetics of bladder cancer. $\mathrm{Br} J$ Urol 1995, 75:57-66.

27. Orlando V: Polycomb, epigenomes, and control of cell identity. Cell 2003, I I 2:599-606.

28. Jacobs JJ, Kieboom K, Marino S, Depinho RA, van Lohuizen M: The oncogene and Polycomb-group gene bmi-I regulates cell proliferation and senescence through the ink4a locus. Nature 1999, 397:164-168.

29. Kang MK, Kim RH, Kim SJ, Yip FK, Shin KH, Dimri GP, Christensen $\mathrm{R}$, Han $\mathrm{T}$, Park NH: Elevated Bmi-I expression is associated with dysplastic cell transformation during oral carcinogenesis and is required for cancer cell replication and survival. $\mathrm{Br}$ J Cancer 2007, 96: 126-133.

30. Park IK, Morrison SJ, Clarke MF: Bmi-I, Stem cells, and senescence regulation. I Clin Invest 2004, I I 3: I75- I79.

31. Dimri GP, Martinez JL, Jacobs JJ, Keblusek P, Itahana K, van Lohuizen $M$, Campisi J, Wazer DE, Band V: The Bmi-I oncogene induces telomerase activity and immortalizes human mammary epithelial cells. Cancer Res 2002, 62(16):4736-4745.

32. Ball AJ, Levine F: Telomere-independent cellular senescence in human fetal cardiomyocytes. Aging Cell 2005, 4:2I-30.

33. Reinisch CM, Uthman A, Erovic BM, Pammer J: Expression of BMI$I$ in normal skin and inflammatory and neoplastic skin lesions. J Cutan Pathol 2007, 34:174-180.

34. Chang LL, Yeh WT, Yang SY, Wu WJ, Huang CH: Genetic alterations of p I6INK4a and p I 4ARF genes in human bladder cancer. J Urol 2003, I 70:595-600.

\section{Pre-publication history}

The pre-publication history for this paper can be accessed here:

http://www.biomedcentral.com/1471-2407/9/61/prepub

Publish with Bio Med Central and every scientist can read your work free of charge

"BioMed Central will be the most significant development for disseminating the results of biomedical research in our lifetime."

Sir Paul Nurse, Cancer Research UK

Your research papers will be:

- available free of charge to the entire biomedical community

- peer reviewed and published immediately upon acceptance

- cited in PubMed and archived on PubMed Central

- yours - you keep the copyright 